$$
\text { JOES } \begin{aligned}
& \begin{array}{l}
\text { Journal } \\
\text { of Educational } \\
\text { Study }
\end{array} \\
& \text { Study }
\end{aligned}
$$

ISSN 2798-0650

Volume 1 Issue 22021

DOI: $10.36663 /$ joes.v1i2.137

\title{
The Use of Mind Map Technique to Improve Study Group Students' Skill in Writing Descriptive Text
}

Kadek Diana Arista, STKIP Agama Hindu Singaraja, Indonesia diianaaristha@gmail.com

\begin{abstract}
This study was conducted to improve the study group students' skill in writing descriptive text using mind map technique. The subjects of the study were 9 students in Dana Punia Orphanage Singaraja. The data obtained was descriptively analyzed. The mean score of the pre-test was $54.5 \%$, which was categorized as being poor to fulfill the students' minimum standard score. After the treatment was conducted, the mean score of the students increased to $69.6 \%$ in the first cycle, and then increased to $75.3 \%$ after conducting cycle 2. The result of the study showed that the students' achievement in writing descriptive text improved, it meant that the Mind Map technique was a very effective technique to be applied in writing descriptive text. This study is expected could be used as a reference for other researchers in conducting further study related to the teaching of writing in school, also as a comparison study for conducting technique in teaching writing especially using mind map Technique.
\end{abstract}

Keywords: descriptive text, mind map technique, writing

\section{Introduction}

English is one of the foreign languages used to communicate with people around the world. In Indonesia, English is the first foreign language used in the fields of economy, health, business world, cultural interchange, political issues tourism and education. In the field of education, according to Harmer (2002) as a subject in school, English has four basic skills, which include reading, listening, speaking and writing. All of these skills cannot be separated from one another if expects to be able to communicate freely in English and should be mastered by students. Writing is one aspect of language skills that needs to be teach regularly and continuously to students. Through writing students are expected to be able to improve writing skills through understanding and training carried out in the classroom. 


\section{JoES $\mid \begin{aligned} & \text { Journal } \\ & \text { of Educational } \\ & \text { Study }\end{aligned}$}

ISSN 2798-0650

Volume 1 Issue 22021

DOI: $10.36663 /$ joes.v1i2.137

In the preliminary interviewed with 9 junior high school students in Dana Punia Orphanage about students writing condition, there were some difficulties faced by students in writing activity especially in writing descriptive text. This was due to the obstacles that came from the students themselves such as they were less interested, had difficulties to develop and expressing their ideas, unable to generate and organize their idea in writing descriptive text. From the results of pre-test stage, it was found that students' writing achievement was low, this was proven from the pre-test outcomes obtained from 9 junior high school students in Dana Punia Orphanage had not reached the minimum completeness. The results of writing descriptive text were far from the level of completeness of the expected achievement.

Every student has different characteristics in learning. Students who learn English will be successful if the learning strategies or techniques are interrelated with those needed by students in teaching and learning activities. One technique that can help students to generate ideas in writing descriptive text is Mind Map. Mind Map technique is the easiest way to place information into the brain and take information out of the brain (Buzan, 1993: 4). Through mind map, students will have opportunity to make some pictures with colorful lines, symbols or signs to help them remember the words or the facts in their mind maps. The use of mind maps in the learning process able train students to think analytically to describe topics that are themes in writing descriptive texts.

Hyland (2003:9) defines writing as a way of sharing personal meanings, writing courses emphasize the power of the individual to construct her or his own views on a topic. Teaching writing skills has a practical purpose which means that students can express their imagination or thoughts in written form, not just a theory that must be understood or memorized and easily forgotten. In addition, writing means expressing feelings, thoughts and desires in writing. According to Miller (2006:7), four stages will make writing better and effective. Those stages are: 1) Planning, first stage of writing and has purpose to capture and preserve ideas, 2) Drafting, the purposes are to let the ideas develop, expand, and form connections, 3) Revising, a writer reshapes ideas such as expanding, deleting, and clarifying, 4) Editing, finding and eliminating mistakes that distract or annoy the reader. The purposes of writing are to make relationship with other, to solve problem in written form such as send a letter for someone.

Descriptive text is a type of text that is widely used in everyday life in describing objects, places, humans, animals and so on. Gerot and Peter (1995) in Masitoh et al state the social function of descriptive text is to describe a particular person, place, or thing. In writing a descriptive text, the writer will be involved in observing a certain object and then it is absorbed, imagined in the mind, and then put it in the form of writing. Gerot and Peter (1995) in Masitoh et al state that the generic structure of descriptive text are identification and description. Identification is introduced 


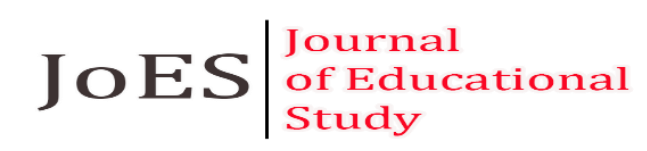

ISSN 2798-0650

Volume 1 Issue 22021

DOI: $10.36663 /$ joes.v1i2.137

the thing that we want to describe or identifies the phenomenon to be described and description is the last part that contains topics such as physical appearance, quality, general behavior and characteristics. According to McKey (1983: 17) descriptive writing is to describe something such as places, people, or other objects

Mind Map technique was developed in the 1970s by Tony Buzan based on research into how the real brain works. According to Buzan, mind map incorporates pictures and different colors bring ideas to life. Tony Buzan (2005) in Edem states that we can use mind-maps for planning, communicating, being more creative, saving time, problem-solving, remembering, faster learning and so on. It is means that mind map has the function in developmental in teaching and learning activities. Mind map is a simple technique that can be used to note creatively and effectively, also help the students to memorize information. People can emerge and organize ideas to be a good sentence by using mind map. Moreover, mind map can make the students happy in studying because of the words, pictures, curvy lines or branches, and colorful lines. That is why mind map is a technique that can be used to learn writing skills.

On the other hand, Mind Map has benefits in teaching and learning, there are: automatically inspire interest in the students, thus making more receptive and cooperative in the classroom, make lessons and presentations more spontaneous, creative and enjoyable, both for teacher and the students, Mind map presents relevant material in a clear and memorable form, Mind map gives the students a deeper understanding of the subject. While, the disadvantages of mind map are such as: mind Map needs a lot of time in organization, Mind Map has difficulties to allocate the time, mind Map needs many times to find an effective keyword.

After conducting a literature review, researcher found five studies on English learning that had been conducted previously that could support this research. The first study was conducted by Putu Yogin Riastama with the title "The Effectiveness of Using Mind Mapping Technique on Writing Skill Descriptive Text at Seventh Grade of SMP Negeri 1 Banjar In Academic Year 2018/2019" The result of his study was Mind Mapping Technique more effective to teach descriptive text at seventh grade students of SMP Negeri 1 Banjar. Next research was "Learning to Write a Descriptive Paragraph with a Mind Mapping Model" written by Ida Bagus Putrayasa and Harls Evan R. Siahaan. The results of this research showed that the implementation of the instruction in writing descriptive paragraph using mind mapping model by the teachers has closely followed the existing theory and the ability of the seventh grades students of SMP Negeri 2 Singaraja in writing descriptive paragraph using mind mapping fell into category good.

Third research was "Students' Writing Ability in Writing Descriptive Text by Using Mind Mapping Technique (A Classroom Action Research in Class X-A UPW)" by Beti Sugiharti, Sudirman, Gede Sukerama. Their research showed that mind mapping is a suitable technique to 


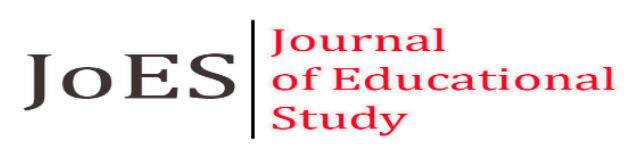

ISSN 2798-0650

Volume 1 Issue 22021

DOI: 10.36663/joes.v1i2.137

improve the students' ability in writing descriptive text in SMK Negeri 1 Singaraja academic year 2018/2019.Fourth research was “The Use of Mind Mapping Picture to Improve Students' Writing Skill of Descriptive Text at Grade VIII Of SMP S Johan Sentosa" written by Debi Eka Sukma from STKIP Insan Madani Airmolek. The result of her research, there were improvement in students' writing and the factors that influenced the improvement of students' writing involved media and material. Her research showed that the implementation of mind mapping picture in teaching writing of descriptive text could provide satisfied result on students' writing skill.

The fifth research was conducted by Suratmi (2020) with the title "Mind and Map Method: Efforts to Improve Descriptive Text Writing Skills for Students at MTs Negeri 4 Bantul". The results of her research are the mind map technique was one of the learning techniques of writing that is able to improve the activity and skills of the student writing the description text. Here, the researcher had different study. The study was about the "The Use of Mind Map Technique to Improve Study Group Students' Skill in Writing Descriptive Text”. The differences between this research and others are: the subjects of the researchers are the students live in Dana Punia Orphanages, they are at different grades of education, grades 7, 8 and 9. This study would focus on the achievement of writing in descriptive text using mind map technique

\section{Method}

This research used Classroom Action Research (CAR). Mills (2003) in Kunlasomboon et al states an action research as any systematic inquiry conducted by teacher researchers, principals, and school counselors in the teaching and learning environment to gather information about how their particular school operates, teachers teach, and well their students learn. This research was conducted to overcome the problem of students in Dana Punia Orphanage in writing descriptive text. In this research was done in two cycles which involved four steps for one cycle with each cycle consisted of planning, action, observation and reflection. It was done by admitting the model that is suggested by Kemmis and McTaggart (1988) in Purrochman.

This research was conducted in Dana Punia Orphanage which was located in Singaraja. The participants were junior high students in 2020/2021 academic year consisting of 9 students. The students consist with 5 males and 4 females. There were four instruments in this research, namely: pre-test and post-test, lesson plan, interviews guide and observation sheet. The data were analyzed quantitatively and qualitatively. There were some methods of collecting data that were uses in this research. They were observation, interview and test. In this case the data was taken from the source by employing observation and test.

The obtain data in this study were categorized into quantitative data, and qualitative data. The qualitative data was the data in the form of information, which was obtain from the students' 


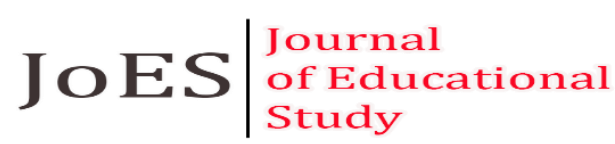

ISSN 2798-0650

Volume 1 Issue 22021

DOI: $10.36663 /$ joes.v1i2.137

attitude scale by questionnaire, and was analyzed descriptively. With the method of analyzing qualitative data, the researcher did and made data tabulation, data category and data interpretation, and then drew the conclusion from the analysis.

The quantitative data were obtained from the results of the tests that were carried out at the end of each cycle. The quantitative data were analyzed descriptively. In this data analysis, the mean score showed the degree of improvement achieved by the students after following the teaching and learning process through the implementation of mind map technique.

\section{Findings}

This classroom action research is divided into pre-liminary stage, cycle I and cycle II. The pre-stage was carried out on Saturday, 6 February 2021 at 09:00 - 11:00 WITA. The pre-test was conducted in order to know the students' achievement in writing Descriptive text. Based on the result of the pre-stage, the average score obtained of students had not reached the completeness standard, namely, 70 . The overall average score of students has only reached $54.5 \%$, it means out of 9 students only 1 person met the completeness criteria in learning to write descriptive text. The following was a table of the results of students' initial abilities in writing descriptive text.

Table 1. Results of the pre-test

\begin{tabular}{|c|c|c|c|c|c|c|c|c|}
\hline \multirow{2}{*}{ No } & \multirow{2}{*}{ Subject } & \multicolumn{5}{|c|}{ Indicator assessment } & \multirow{2}{*}{$\begin{array}{l}\text { Total } \\
\text { score }\end{array}$} & \multirow{2}{*}{ Category } \\
\hline & & $\mathbf{C}$ & $\mathbf{O}$ & $\mathbf{V}$ & $\mathbf{G}$ & $\mathbf{M}$ & & \\
\hline 1 & S1 & 21 & 14 & 9 & 10 & 2 & 56 & Poor \\
\hline 2 & S2 & 20 & 13 & 10 & 10 & 2 & 55 & Poor \\
\hline 3 & S3 & 20 & 10 & 10 & 9 & 2 & 51 & Poor \\
\hline 4 & S4 & 20 & 9 & 9 & 9 & 2 & 49 & Very poor \\
\hline 5 & S5 & 17 & 9 & 10 & 8 & 2 & 46 & Very poor \\
\hline 6 & S6 & 16 & 9 & 9 & 8 & 2 & 44 & Very poor \\
\hline 7 & S7 & 22 & 17 & 17 & 15 & 3 & 74 & Good \\
\hline 8 & S8 & 20 & 12 & 10 & 10 & 3 & 55 & Poor \\
\hline 9 & S9 & 20 & 10 & 13 & 14 & 3 & 60 & Fair \\
\hline \multicolumn{2}{|c|}{ Sum } & 176 & 103 & 103 & 93 & 21 & 490 & \\
\hline \multicolumn{2}{|c|}{ Mean } & 19,5 & 11,4 & 11,4 & 10,3 & 2,3 & 54,5 & Poor \\
\hline
\end{tabular}

Cycle I was carried out on March 1 and 2, 2021. This research was carried out in four stages, namely planning, action, observation and reflection. In this stage, researcher then compiled the lesson plan by adding a mind map technique as a stimulus in developing students' imagination in writing descriptive text. Before teaching and learning process was conducted, researcher made planning such as designing the lesson plan, preparing the observation form, post-test 1 and the 


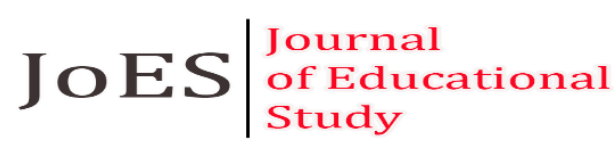

ISSN 2798-0650

Volume 1 Issue 22021

DOI: $10.36663 /$ joes.v1i2.137

questionnaire needed, the writing material, teaching media for writing descriptive text. The following were the results of the students' post-test in cycle I

Table 2. The Results of post-Test cycle I

\begin{tabular}{|c|c|c|c|c|c|c|c|c|}
\hline \multirow{2}{*}{ No } & \multirow{2}{*}{ Subject } & \multicolumn{5}{|c|}{ Indicator assessment } & \multirow{2}{*}{ Total score } & \multirow{2}{*}{ Category } \\
\hline & & $\mathbf{C}$ & $\mathbf{O}$ & $\mathbf{V}$ & $\mathbf{G}$ & $\mathbf{M}$ & & \\
\hline 1 & S1 & 22 & 15 & 14 & 15 & 3 & 69 & Fair \\
\hline 2 & S2 & 22 & 15 & 12 & 14 & 3 & 66 & Fair \\
\hline 3 & S3 & 22 & 14 & 15 & 12 & 3 & 66 & Fair \\
\hline 4 & S4 & 23 & 10 & 13 & 12 & 3 & 61 & Fair \\
\hline 5 & S5 & 23 & 14 & 14 & 16 & 3 & 70 & Good \\
\hline 6 & S6 & 23 & 13 & 14 & 15 & 3 & 68 & Fair \\
\hline 7 & S7 & 24 & 17 & 17 & 16 & 4 & 78 & Good \\
\hline 8 & S8 & 24 & 16 & 16 & 16 & 4 & 76 & Good \\
\hline 9 & S9 & 23 & 15 & 15 & 16 & 4 & 73 & Good \\
\hline \multicolumn{7}{|c|}{ Sum } & 627 & \\
\hline \multicolumn{7}{|c|}{ Mean } & 69,6 & Fair \\
\hline
\end{tabular}

From the resulted of the post-test on cycle I, the learning process of writing descriptive text has increased significantly, from $54.5 \%$ to $69.6 \%$. Out of 9 students, 4 students were able to write descriptive text using mind map technique and 5 of them had not met the completeness criteria but had significant improvement compared to the pre-test.Cycle II was carried out on March 8 and 9, 2021. Similar to cycle I, this research was carried out in four stages, namely planning, action, observation and reflection. From the results of the students' work in writing descriptive text using mind map techniques, there has been a significant increase. This can be seen from the average results of students in cycle II, namely $75.3 \%$. The following were the results of the students' posttest in cycle II.

Table 3.The results of the students' post-test in cycle II.

\begin{tabular}{|c|c|c|c|c|c|c|c|c|}
\hline \multirow{2}{*}{ No } & \multirow{2}{*}{ Subject } & \multicolumn{5}{|c|}{ Indicator assessment } & \multirow{2}{*}{ Total score } & \multirow{2}{*}{ Category } \\
\hline & & $\mathbf{C}$ & $\mathbf{O}$ & $\mathbf{V}$ & $\mathbf{G}$ & $\mathbf{M}$ & & \\
\hline 1 & S1 & 24 & 15 & 16 & 15 & 4 & 74 & Good \\
\hline 2 & $\mathrm{~S} 2$ & 23 & 15 & 16 & 16 & 4 & 74 & Good \\
\hline 3 & S3 & 23 & 15 & 16 & 13 & 4 & 71 & Good \\
\hline 4 & $\mathrm{~S} 4$ & 23 & 11 & 15 & 12 & 3 & 64 & Fair \\
\hline 5 & S5 & 23 & 15 & 15 & 16 & 4 & 73 & Good \\
\hline 6 & S6 & 26 & 17 & 17 & 16 & 4 & 80 & Very good \\
\hline 7 & S7 & 26 & 17 & 17 & 17 & 4 & 81 & Very good \\
\hline
\end{tabular}




$$
\text { JOES } \begin{aligned}
& \begin{array}{l}
\text { Journal } \\
\text { of Educational } \\
\text { Study }
\end{array}
\end{aligned}
$$

ISSN 2798-0650

Volume 1 Issue 22021

DOI: $10.36663 /$ joes.v1i2.137

\begin{tabular}{|c|c|c|c|c|c|c|c|c|}
\hline 8 & S8 & 25 & 16 & 17 & 16 & 4 & 78 & Good \\
\hline 9 & S9 & 26 & 17 & 18 & 18 & 4 & 83 & Very good \\
\hline \multicolumn{7}{|c|}{ Sum } & 678 & \\
\hline \multicolumn{7}{|c|}{ Mean } & 75,3 & \\
\hline
\end{tabular}

The table above shows a significant increase from cycle I to cycle II. This is evidenced by the average acquisition of the first cycle, namely $69.6 \%$ to $75.3 \%$ in the second cycle. In addition, the number of students who reached the minimum completeness criteria also increased from 4 students to 8 students.

\section{Discussions}

The discussion of the research results aimed to determine whether the mind map technique was able to improve the skill of study group students' skill in writing descriptive text at Dana Punia Orphanage, Singaraja. The data discussed was the improvement of students' skill in writing descriptive text using mind map technique. The following was a graph of the increased in the average score of students in writing descriptive text using mind map technique.

Graph 1. The Improvement in writing descriptive text

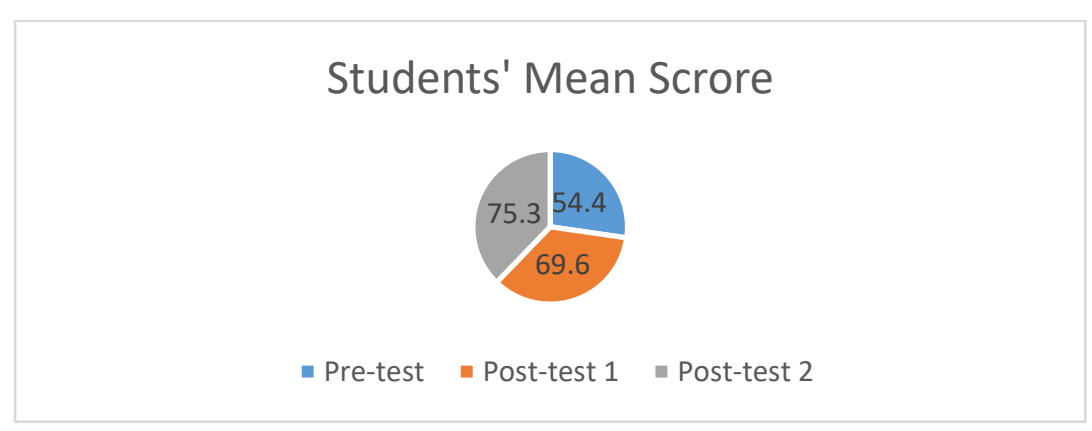

The data on the graph 1 showed the gradual improvements from pre-test, post-test 1 to post-test 2 . The students' mean score in pre-test was 54.5 which means belonged to 'poor' category from 9 students taking the test, 3 students (33.3\%) achieved very poor level of mastery, 4 students (44.4\%) achieved poor level of mastery, 1 student (11.1\%) achieved fair level of mastery, and 1 student $(11.1 \%)$ achieved good level of mastery and could pass the passing score. In cycle 1 , the mean score of the students was 69.6. In this cycle, the students' mean score increased 15.2 points to 69.6 from pre-test. From 9 students followed the test, 5 (55.5\%) students achieved fair level of mastery and 4 (44.4\%) students achieved good level mastery and could pass the passing score. The action was continued to cycle 2 . In this cycle, the students' mean score increased 5.7 points to 75.3 from cycle 1. From 9 students following test, 5 students (55.5\%) achieved good level of mastery, $3(33.3 \%)$ students achieved very good level of mastery, but there were $1(11.1 \%)$ student could not the passing score. The students' mean score in cycle 2 had already reached the passing grade 


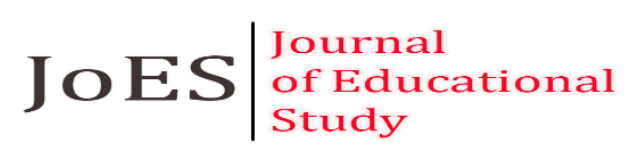

ISSN 2798-0650

Volume 1 Issue 22021

DOI: $10.36663 /$ joes.v1i2.137

then the action was stopped. For individual score of the students, could be seen in appendix. According to the result of the tests in each cycle, it was found that there were a number of students who had insufficient achievement in writing achievement. The number and the percentages of the students who reached and did not passing score in each cycle are explained in Table 4

Table 4 The Percentages of the Students Who Reached and Did Not Reach the Passing Score in Each Cycle

\begin{tabular}{|l|l|l|l|l|}
\hline Test & $\begin{array}{l}\text { Number of students who } \\
\text { reached passing score }\end{array}$ & $(\%)$ & $\begin{array}{l}\text { Number of did not } \\
\text { reach the passing } \\
\text { score }\end{array}$ & $(\%)$ \\
\hline Pre-test & 1 & $11.1 \%$ & 8 & $88.8 \%$ \\
\hline Post-test 1 & 4 & $44.4 \%$ & 5 & $55.5 \%$ \\
\hline Post-test 2 & 8 & $88,8 \%$ & 1 & $11.1 \%$ \\
\hline
\end{tabular}

The result of the students' score after being given the action indicated that the application of mind map technique helped the students gained some improvements in writing achievement specifically in writing descriptive text. In this research, the result of pre-test, post-test 1 , and posttest 2, all of the students had made significant improvement in writing achievement. However, there were 1 student still could not reach the passing score. After doing an analysis of the answer, the organization in each paragraph was less organized. In addition, the use of grammar and writing mechanisms was still lacking. Referring to this fact, it must be decided that this student must be given special attention in the classroom. However, from pre-test to post-test, this student showed improvements although could not pass the passing score. From the explanation above, it could be concluded that the use of Mind Map technique helped the students' achievement in writing descriptive text

\section{Conclusion and Suggestion}

Based on the findings and the discussion presented in chapter 4, the conclusion of the present study could be presented that the use of mind map technique in writing descriptive text could improve the achievement of study group students in Dana Punia Orphanage Singaraja. The students' improvement could be seen from the result of the pre-test, post-test 1, and post-test 2 that gradually increased. The mean score of the pre-test was $54.5 \%$, which was categorized as being poor to fulfill the students' minimum standard score. After the use of the mind map technique, the students' problems in writing descriptive text were overcome. The mean score of the students increased to $69.6 \%$ in the first cycle, and then increased to $75.3 \%$ in cycle 2 . Although, there was still 1 student who could not reach the minimum score, however, this could be considered to pass 


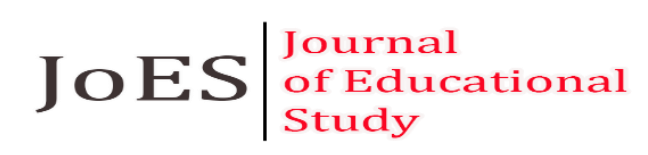

ISSN 2798-0650

Volume 1 Issue 22021

DOI: $10.36663 /$ joes.v1i2.137

the criteria of students' mastery level in writing. Since these achievements were caused by the use of the mind map technique during the teaching and learning process, it meant that the Mind Map technique was a very effective technique to be applied to improve the students' writing achievement in writing descriptive text.

Referring to the conclusion, there were some suggestions that could be addressed to the students, the English teachers and other researchers. Those suggestions were: students should use the Mind Map technique every time they have a writing class, English teachers of Junior High Schools, should apply the Mind Map technique in teaching writing descriptive texts to improve the students' skill in writing achievement and also can be used as a reference for other researchers in conducting further study related to the teaching of writing in school. It also can be used by the other researchers as a comparison study for conducting technique in teaching writing especially using mind map technique.

\section{References}

Buzan, T. The Mind Map Book - Tony Buzan. Retrieved on January 1 ${ }^{\text {st }}, 2021$ from Scribd: Https://id.scribd.com/doc/7064184/The-Mind-Map-Book-Tony-Buzan

Edem, A. (2021). Mind Maps as a Lifelong Tool. Retrieved January $2^{\text {nd }}, 2021$ from Universal Journal of Educational Research: https://files.eric.ed.gov/fulltext/EJ1165490.pdf

Harmer, J. (2002). How to Teach English. United Kingdom: Longman.

Hyland, K. (2003). Second Language Writing. New York: Cambride University Press.

Karsinah et al. (n.d). Teaching Descriptive Text Writing by Atribute Listing to SMK. Retrieved January 29 2021 from Ristekdikti: http://download.garuda.ristekdikti.go.id/article.php?article+1563664\&val+2338\&title=Te aching\%20Descriptive

\%20Text\%20Writing\%20by\%20Atribute\%20Listing\%20to\%20SMK

Kunlasomboon et al. Research and Development of Classroom Action Research Process to Enhance School Learning. Retrieved February $1^{\text {st }}$, 2021 from ScieneDirect: https://core.ac.uk/download/pdf/82413072.pdf

Masitoh at al. (2021, January 18). Improving Students Ability in Writing Descriptive Text Using Genre Based Approach (GBA) at the Eighth Grade Students of SMP Islam Terpadu Fitrah Insani. Retrieved from E-journal STKIP Siliwangi: http://ejournal.stkipsiliwangi.ac.id/index.php/eltin/article/download/120/109

Miller, R. K. (2006). Motives for Writing Fifth Edition. New York: McGraw-Hill.

McKey, S. (1983). Fundamental of Writing for a Specific Purpose. London: Prentice Hill.

Purrochman, P. S. Clasroom Action Research Alternative Research Activity for Teacher. Retrieved February 1st, 2021 from Research http://www.researchgate.net/publication/326083037_Clasroom_Action_Research_Altern ative_Research_Activity_for_Teacher 